\title{
Rankings In The Euro Zone Based On Macroeconomic Information
}

\author{
Ma Carmen García-Centeno, Ph.D., CEU San Pablo University, Spain \\ Jorge Uxó, Ph.D., University of Castilla-La Mancha, Spain \\ Román Mínguez, Ph.D., University of Castilla-La Mancha, Spain
}

\begin{abstract}
One consequence of the Great Recession that began in 2008 has been the sovereign debt crisis within the European Monetary Union (EMU) and the increasing risk premium associated with government debt of "peripheral" countries (primarily, Greece, Ireland, Portugal and Spain). Firstly, this paper analyses what macroeconomic variables are more related with the evolution of the risk premium, using panel data estimation. Secondly, we also try to sort the countries belonging to the monetary union in terms of their likelihood of experiencing an increase in the risk premium. To this purpose, we use discrete multicriteria decision aid methods.
\end{abstract}

Keywords: Risk premium; Sovereign Debt; Economic and Monetary Union; Macroeconomic Imbalances

\section{INTRODUCTION}

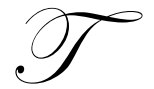

he first decade of operation of the Economic and Monetary Union (EMU) was characterized by the virtual elimination of risk premia among member countries, so that the 10-year bonds yields were very similar. However, one consequence of the downturn has been precisely the sovereign debt crisis, and the sharp rise in risk premia related to some countries (Figure 1).

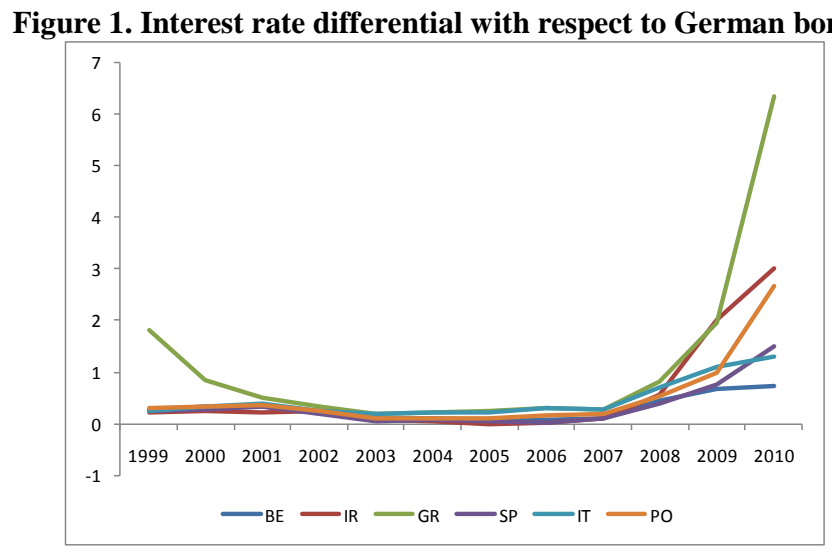

Source: Eurostat

In this context, the European Commission (2010) proposed the adoption of a new mechanism for the prevention and correction of macroeconomic imbalances. Among other measures, it suggested to select a set of indicators, yet undefined ${ }^{1}$, to detect macroeconomic imbalances that should be corrected to avoid the appearance of situations like the current economic crisis. Similarly, Gros and Mayer (2010) proposed a "vulnerability index" composed of different macroeconomic variables to measure the degree to which a country may face an abrupt withdrawal of funding from international markets.

\footnotetext{
${ }^{1}$ See Deutsche Bank (2011) for a discussion of the various alternatives that could be used.
} 
Our work is connected with this idea of extracting information from the macroeconomic variables of a country to know the likelihood of facing an increase in its risk premium and, therefore, suffering a debt crisis. Specifically, our aim is to analyze how macroeconomic variables explain further the differences in the risk premium for EMU countries ${ }^{2}$ in the international debt markets, and build from these variables a ranking with these countries sorted according to their likelihood of experiencing higher risk premiums.

To this end, we consider first a panel data model with fixed effects and quarterly data for the period 1999-1 to 2010-4, in which the risk premium is the dependent variable and there are seven independent variables (GDP growth rate, public debt, public budget balance, current account balance, unit labor costs -compared through the evolution of the real effective exchange rate-, net international investment position and private debt). In all cases the source is Eurostat, and Table 1 shows the details of each of these variables. This analysis gives an estimate of the effects of the variation of each of these variables on changes in the risk premium.

A second analysis has been conducted to find out if we could sort the euro zone countries from the information obtained for these macroeconomic variables using multicriteria decision aid techniques, so that they will reproduce the order established de facto by international financial market through risk premia. In this case the data are annual and we have built this "ranking" in 2007 (the onset of the crisis) and 2010.

Table 1. Macroeconomic variables

\begin{tabular}{|c|c|c|}
\hline Macroeconomic variable & Meaning & Annual and quarterly data \\
\hline Real GDP growth & $\begin{array}{l}\text { A high rate of growth improves the economy's } \\
\text { solvency (ability to meet debt service) }\end{array}$ & $\begin{array}{l}\text { Eurostat provides annual and quarterly data. In this last case we } \\
\text { use the seasonally adjusted percentage change compared to the } \\
\text { same quarter of the previous year }\end{array}$ \\
\hline Public Debt (\% GDP) & Higher debt levels reduces the borrower's solvency & $\begin{array}{l}\text { Eurostat only provides annual data. In all the quarters of the same } \\
\text { year we use the value of the previous year }\end{array}$ \\
\hline Public Budget Balance (\% GDP) & Public deficits imply the need to issue debt & $\begin{array}{l}\text { Eurostat only provides annual data. In all the quarters of the same } \\
\text { year we use the value of the previous year }\end{array}$ \\
\hline Current Account (\% GDP) & $\begin{array}{l}\text { If this balance is negative, the country is borrowing } \\
\text { from abroad and increas ing its external debt }\end{array}$ & Eurostat provides annual and quarterly data \\
\hline $\begin{array}{l}\text { Real Effective Exchange Rate versus } 36 \\
\text { partners (REER-36; 1999=100) }\end{array}$ & $\begin{array}{l}\text { It is calculated taking into account the unit labor cost } \\
\text { (total economy). A value higher than } 100 \text { means loss } \\
\text { of competitiveness }\end{array}$ & Eurostat provides annual and quarterly data \\
\hline Net International Investment Position (\% GDP) & $\begin{array}{l}\text { Difference between external assets and external } \\
\text { liabilities }\end{array}$ & $\begin{array}{l}\text { Eurostat only provides annual data. In all the quarters of the same } \\
\text { year we use the value of the previous year }\end{array}$ \\
\hline $\begin{array}{l}\text { Private debt (non-financial corporations and } \\
\text { households+NPISH; \% GDP) }\end{array}$ & Higher debt levels reduces the borrower's solvency & $\begin{array}{l}\text { Eurostat only provides annual data. In all the quarters of the same } \\
\text { year we use the value of the previous year }\end{array}$ \\
\hline $\begin{array}{l}\text { Risk premium (diferential with respect to } \\
\text { Germany) }\end{array}$ & $\begin{array}{l}\text { Difference between the 10-years bond yields in a } \\
\text { contry and in Germany }\end{array}$ & $\begin{array}{l}\text { Eurostat provides annual and monthly data. Each quarter is the } \\
\text { average of the three corresponding months }\end{array}$ \\
\hline
\end{tabular}

Source: Own elaboration

\section{ANALYSIS USING PANEL DATA TECHNIQUES}

The panel data model allows to express the risk premium in country $i$ at time $t$, given by $y_{i t}$, as a function of the particular characteristics of each country at every moment, collected in the vector $\boldsymbol{x}_{i t}$, an idiosyncratic component stable in the time, $\alpha_{i}$, and a random noise. Under the assumptions of linearity, homoscedasticity and absence of temporal and spatial correlation in the random noise, the model can be expressed as:

${ }^{2}$ We will refer only to EMU-12, except Luxembourg. 
$y_{i t}=x_{i t}^{T} \beta+\alpha_{i}+u_{i t} \quad u_{i t} \sim N\left(0, \sigma^{2}\right), \quad \operatorname{Cov}\left(u_{i t}, u_{j s}\right)=0 \quad \forall i \neq j, t \neq s$

In our case, the idiosyncratic component is considered a constant parameter to estimate, that is, a separate intercept for each country (fixed effects model), since, in this context, this model is preferable to random effects model $^{3}$. Therefore, the optimal method of estimation (under the assumptions mentioned above) is to use ordinary least squares with a dummy variable for country, or LSDV (Baltagi, 2005; Greene, 2008). The estimation results with quarterly data from 1999-1 to 2010-4 are shown in Tables 2 and 3 (the panel is unbalanced because some countries do not have available the entire time span):

Table 2. Determinants of risk premium for the whole sample (panel data model with fixed effects, unbalanced, 1999-1 to 2010-4)

\begin{tabular}{|l|c|c|c|c|}
\hline & Estimate & Std. Error & t-value & Pr $(>|\mathbf{t}|)$ \\
\hline GDP growth & -0.0912707 & 0.0100942 & -9.0419 & $<2.2 \mathrm{E}-16 * * *$ \\
\hline Public Debt & 0.0256993 & 0.0045060 & 5.7033 & $2.12 \mathrm{E}-055^{* * *}$ \\
\hline Public Budget Balance & -0.0651856 & 0.0133209 & -4.8935 & $1.38 \mathrm{E}-03 * * *$ \\
\hline Current Account & 0.0115576 & 0.0078920 & 1.4645 & 0.1437581 \\
\hline Unit labor cost & -0.0153132 & 0.0063912 & -2.3960 & $0.0169808 *$ \\
\hline Net Internat. Investment Position & -0.0012988 & 0.0010987 & -1.1821 & 0.2378008 \\
\hline Private Debt & 0.0054950 & 0.0015775 & 3.4834 & $0.0005432 * * *$ \\
\hline
\end{tabular}
$\mathrm{n}=11, \mathrm{~T}=32-48, \mathrm{~N}=471$

Source: Own elaboration based on Eurostat data

Table 3. Country fixed effects (whole sample, 1999-1 to 2010-4)

\begin{tabular}{|l|c|c|c|c|}
\hline & Estimate & Std. Error & t-value & Pr $(>|\mathbf{t}|)$ \\
\hline Austria & -0.0077411 & 0.7004794 & -0.0111 & 0.9912 \\
\hline Belgium & -0.9487172 & 0.8342158 & -1.1314 & 0.2554 \\
\hline Finland & 0.7860492 & 0.6947384 & 1.1314 & 0.2579 \\
\hline France & -0.0839071 & 0.7203993 & -0.1165 & 0.9073 \\
\hline Germany & -0.4208963 & 0.6831865 & -0.6161 & 0.5378 \\
\hline Greece & -0.0488901 & 0.8692511 & -0.0562 & 0.9551 \\
\hline Ireland & 1.1260943 & 0.7121939 & 1.5812 & 0.1138 \\
\hline Italy & -0.7980055 & 0.9040442 & -0.8827 & 0.3774 \\
\hline Netherlands & -0.0661996 & 0.7276317 & -0.0910 & 0.9275 \\
\hline Portugal & -0.0858495 & 0.6920984 & -0.1240 & 0.9013 \\
\hline Spain & 0.5480629 & 0.7045849 & 0.7779 & 0.4367 \\
\hline
\end{tabular}

$\mathrm{F}=12.8959, \mathrm{df} 1=10, \mathrm{df} 2=453, \mathrm{p}$-value $<2.2 \mathrm{E}-16$

Alternative hypothesis: significant effects

Source: Own elaboration based on Eurostat data

The estimation results show that the most important determinants of the risk premium are the next ones: debt (public and private), public budget balance and GDP growth. To a lesser extent, the competitiveness, through unit labor costs, also seems to influence the risk premium. All coefficients have the expected signs and the individual effects F test, with the pooled model (including only an intercept) as the null hypothesis against the fixed effects models as the alternative hypothesis, clearly rejects the null hypothesis. With respect to the fixed effect of each country (with an average level equals to zero) is important to note the positive values of Ireland, Finland and Spain (countries penalized in their risk premium taking into account their economic determinants) and the negative values in Belgium, Italy and Germany (countries benefited in their risk premium).

We have repeated the same analysis with a shorter sample (from 2007-1 to 2010-4) to isolate the period of crisis, and the results are given in Tables 4 and 5. It is important to highlight that during the crisis period neither the

\footnotetext{
${ }^{3}$ The latter model would be preferable whether the examined countries were considered as a random sample of a population of more countries, which is not the case.
} 
private debt nor the public budget balance seem to influence the risk premium while, on the other hand, the external deficit is now significant. With respect to the public debt and the GDP growth, both remain clearly significant, indicating their importance in determining the risk premium. The individual effects $F$ test has obtained the same conclusion (fixed effects model preferred in front of pooled model) and the positive fixed effects are accentuated in Ireland and Spain (in fact they increase the punishment in their risk premium during the crisis) and the countries with negative values of fixed effects continue to be Italy and, to a lesser extent, Belgium and Germany (they remain benefited during the crisis).

Table 4. Determinants of risk premium since the beginning of the crisis

(panel data model with fixed effects, unbalanced, 2007-1 to 2010-4)

\begin{tabular}{|l|c|c|c|c|}
\hline & Estimate & Std. Error & t-value & $\operatorname{Pr}(>|\mathbf{t}|)$ \\
\hline GDP growth & -0.1232213 & 0.0219348 & -5.6176 & $8.903 \mathrm{E}-08$ *** \\
\hline Public Debt & 0.0924911 & 0.0181889 & 5.0850 & $1.061 \mathrm{E}-06 \quad * * *$ \\
\hline Public Budget Balance & 0.0271348 & 0.035077 & 0.7736 & 0.4403737 \\
\hline Current Account & 0.0647277 & 0.0181766 & 3.5610 & $0.0004926 * * *$ \\
\hline REER-36 & -0.0428232 & 0.0327192 & -1.3088 & 0.1925617 \\
\hline Net Internat. Investment Position & 0.0060298 & 0.0068721 & 0.8774 & 0.3816316 \\
\hline Private Debt & -0.0061803 & 0.0084308 & -0.7331 & 0.4646377 \\
\hline \multicolumn{1}{|c|}{$\mathrm{n}=11, \mathrm{~T}=12-16, \mathrm{~N}=171$} \\
\hline
\end{tabular}

Source: Own elaboration based on Eurostat data

Table 5. Country fixed effects (sample including the crisis period, 2007-1 to 2010-4)

\begin{tabular}{|l|c|c|c|c|}
\hline & Estimate & Std. Error & t-value & $\operatorname{Pr}(>|\mathbf{t}|)$ \\
\hline Austria & -0.98359 & 3.61005 & -0.2725 & 0.7853 \\
\hline Belgium & -2.61782 & 4.17201 & -0.6275 & 0.5303 \\
\hline Finland & 1.64474 & 3.73981 & 0.4398 & 0.6601 \\
\hline France & -0.67201 & 3.92018 & -0.1714 & 0.8639 \\
\hline Germany & -2.56483 & 3.46094 & -0.7411 & 0.4586 \\
\hline Greece & -1.49504 & 4.6244 & -0.3233 & 0.7465 \\
\hline Ireland & 4.66956 & 4.36323 & 1.0702 & 0.2845 \\
\hline Italy & -3.73657 & 4.64485 & -0.8045 & 0.4211 \\
\hline Netherlands & 0.69692 & 4.02384 & 0.1732 & 0.8625 \\
\hline Portugal & 1.41759 & 4.1756 & 0.3395 & 0.7342 \\
\hline Spain & 3.64106 & 4.1119 & 0.8855 & 0.3759 \\
\hline
\end{tabular}

$\mathrm{F}=6.839, \mathrm{df} 1=10, \mathrm{df} 2=153, \mathrm{p}$-value $8.816 \mathrm{E}-09$

Alternative hypothesis: significant effects

Source: Own elaboration based on Eurostat data

\section{ANALYSIS USING DISCRETE MULTICRITERIA DECISION AID METHODS}

PROMETHEE is one of the most used multicriteria decision aid method (Brans et al., 1984; Brans and Vincke, 1985; Goumans and Lygerou, 2000). These methods are based on the principle of pair-wise comparison. They assume that the decision-maker tends to compare each action one-to-one with other actions when there are different evaluation criteria. This method is able to compare the different criteria independently from their measurement units and define priorities among the criteria.

The pay-off matrix is needed to use the discrete multicriteria decision methods. The main elements of the pay-off matrix are the following:

- The actions: They are the elements that will be ordered by the ranking. In this work, the actions are eleven EMU countries.

- The criteria: The criteria are the variables used to evaluate each country. They can be maximized (an actions is preferred when the value of a criteria is higher than other) or minimized. Each criterion has a 
weight (normalized or not). This weight shows the importance of each criterion to establish a ranking between the different actions, but in this work we suppose that all variables have the same weight. In our case, the criteria are the macroeconomic variables: GDP growth, Public Budget Balance, Current Account Balance and Net International Investment Position are maximized; on the other hand, Public Debt, Private Debt and REER-36 are minimized.

In these methods, the preference function translates the deviation between the evaluations of two actions on a single criterion in terms of a degree of preference. The degree of preference is an increasing function of the deviation: smaller deviations will contribute to weaker degrees of preference and larger ones to stronger degrees of preference. In order to facilitate the association of a preference function to each criterion we chose the usual function without threshold for all criteria (i.e., a country is preferred to another when his macroeconomic results are better).

- $\quad$ The results: In our case, they are the macroeconomic figures of each country.

The pay-off matrices in 2007 and 2010 are shown in Tables 6 and 7 (we have also included, for information, the risk premium data of each year):

Table 6. Pay-off matrix calculated from macroeconomic data for 2007

\begin{tabular}{|l|c|c|c|c|c|c|c|c|}
\hline & GDP Growth & Public Debt & $\begin{array}{c}\text { Public Budget } \\
\text { Balance }\end{array}$ & $\begin{array}{c}\text { Current } \\
\text { Account }\end{array}$ & REER-36 & $\begin{array}{c}\text { Net } \\
\text { International } \\
\text { Investment } \\
\text { Position }\end{array}$ & Private Debt & $\begin{array}{c}\text { Risk } \\
\text { Premium }\end{array}$ \\
\hline Belgium & 2,9 & 84,2 & $-0,3$ & 3,6 & 104,13 & 29,0 & 205,4 & 0,11 \\
\hline Germany & 2,7 & 64,9 & 0,3 & 7,7 & 100,40 & 27,0 & 132,0 & 0,00 \\
\hline Ireland & 5,6 & 25,0 & 0,1 & $-5,6$ & 122,00 & $-19,5$ & 211,4 & 0,09 \\
\hline Greece & 4,3 & 105,4 & $-6,4$ & $-13,3$ & 105,10 & $-95,1$ & 106,5 & 0,28 \\
\hline Spain & 3,6 & 36,1 & 1,9 & $-9,6$ & 112,77 & $-78,1$ & 213,7 & 0,09 \\
\hline France & 2,4 & 63,9 & $-2,7$ & $-2,1$ & 102,85 & $-6,6$ & 144,4 & 0,08 \\
\hline Italy & 1,5 & 103,6 & $-1,5$ & $-1,7$ & 106,50 & $-21,5$ & 114,1 & 0,27 \\
\hline Netherlands & 3,9 & 45,3 & 0,2 & 8,2 & 106,63 & $-6,0$ & 209,5 & 0,07 \\
\hline Austria & 3,7 & 60,7 & $-0,9$ & 4,1 & 99,96 & $-18,3$ & 135,3 & 0,08 \\
\hline Portugal & 2,4 & 68,3 & $-3,1$ & $-8,9$ & 109,91 & $-88,2$ & 229,9 & 0,20 \\
\hline Finland & 5,3 & 35,2 & 5,2 & 4,3 & 101,36 & $-27,9$ & 149,2 & 0,07 \\
\hline
\end{tabular}

Table 7. Pay-off matrix calculated from macroeconomic data for 2010

\begin{tabular}{|l|c|c|c|c|c|c|c|c|}
\hline 2010 & GDP Growth & Public Debt & $\begin{array}{c}\text { Public Budget } \\
\text { Balance }\end{array}$ & $\begin{array}{c}\text { Current } \\
\text { Account }\end{array}$ & REER-36 & $\begin{array}{c}\text { Net } \\
\text { International } \\
\text { Investment } \\
\text { Position }\end{array}$ & Private Debt & $\begin{array}{c}\text { Risk } \\
\text { Premium }\end{array}$ \\
\hline Belgium & 2,2 & 96,8 & $-4,1$ & 2,6 & 105,46 & 44,6 & 217,0 & 0,72 \\
\hline Germany & 3,6 & 83,2 & $-3,3$ & 5,1 & 97,63 & 37,3 & 133,8 & 0,00 \\
\hline Ireland & -1 & 96,2 & $-32,4$ & $-3,4$ & 116,04 & $-98,4$ & 317,2 & 3,00 \\
\hline Greece & $-4,5$ & 142,8 & $-10,5$ & $-10,1$ & 109,48 & $-85,7$ & 123,0 & 6,35 \\
\hline Spain & $-0,1$ & 60,1 & $-9,2$ & $-3,9$ & 113,40 & $-92,1$ & 225,1 & 1,51 \\
\hline France & 1,6 & 81,7 & $-7,0$ & $-2,8$ & 101,57 & $-13,2$ & 160,4 & 0,38 \\
\hline Italy & 1,3 & 119,0 & $-4,6$ & $-4,2$ & 105,60 & $-19,3$ & 119,6 & 1,30 \\
\hline Netherlands & 1,8 & 62,7 & $-5,4$ & 6,0 & 105,60 & 17,4 & 220,5 & 0,25 \\
\hline Austria & 2 & 72,3 & $-4,6$ & 3,3 & 98,69 & $-12,3$ & 147,6 & 0,49 \\
\hline Portugal & 1,3 & 93,0 & $-9,1$ & $-8,5$ & 107,18 & $-109,3$ & 259,6 & 2,66 \\
\hline Finland & 3,1 & 48,4 & $-2,5$ & 2,9 & 101,66 & $-5,4$ & 177,6 & 0,27 \\
\hline
\end{tabular}

Source: Eurostat 
The preference indexes matrix is obtained from the pay-off matrix by systematically comparing each action one-to-one with the others. The preference indexes are calculated as follows:

$I\left(a_{i}, a_{j}\right)=\sum_{i} w_{i} H_{i}(d)$

where $a_{i}, a_{j}$ are two different actions; $w_{i}$ are the normalized weight of each criterion; and, $H_{i}(d)$ is the corresponding result for each preference function.

The PROMETHEE I partial ranking is defined as the simultaneous comparisons of the positive flow, $\phi^{+}$(it is, the degree of preference with which country is preferred on averaged over the other countries) and negative flow, $\phi^{-}$(it is, the opposite of positive flows and they show the degree of dominance on average of a country to other countries). If there are incomparabilities (because a country can be better for positive flow but not for negative flow) a new complete ranking (PROMETHEE II) is needed, computing the net flow $(\phi)$ as a difference between positive and negative flows.

We propose two different scenarios to obtain partial and complete rankings. In the first one, we consider all macroeconomic variables and, in the second one, we only use the significant criteria from the estimation with panel data model with fixed effect and quarterly data during the crisis (sample period, from 2007-1 to 2010-4). The following Tables and Figures summarize the results:

Table 8. Ranking for 2007 with all criteria and ranking according to risk premium

\begin{tabular}{|c|c|c|c|c|c|}
\hline 2007 & Phi Plus & Phi Minus & Phi Net & $\begin{array}{c}\text { Multicriteria } \\
\text { Ranking }\end{array}$ & $\begin{array}{c}\text { Risk Premium } \\
\text { Ranking } \\
\end{array}$ \\
\hline Germany & 0.8667 & 0.1333 & 0.7333 & 1 & 1 \\
\hline Filand & 0.7733 & 0.1733 & 0.6000 & 2 & 3 \\
\hline Netherland & 0.7267 & 0.2200 & 0.5067 & 3 & 2 \\
\hline Austria & 0.6267 & 0.3200 & 0.3067 & 4 & 4 \\
\hline France & 0.5333 & 0.4067 & 0.1267 & 5 & 5 \\
\hline Ireland & 0.4533 & 0.4933 & -0.0400 & 6 & 7 \\
\hline Belgium & 0.4067 & 0.5933 & -0.1867 & 8 & 8 \\
\hline Spain & 0.3933 & 0.5533 & -0.1600 & 7 & 6 \\
\hline Italy & 0.2267 & 0.7733 & -0.5467 & 9 & 10 \\
\hline Portugal & 0.1733 & 0.8200 & -0.6467 & 10 & 9 \\
\hline Greece & 0.1533 & 0.8467 & -0.6933 & 11 & 11 \\
\hline
\end{tabular}

A higher ranking value means a worse macroeconomic situation (multicriteria ranking)

or higher risk premium (risk premium ranking).

Source: Own elaboration based on Eurostat data

Figure 2. Complete Ranking (PROMETHEE II) for 2007 with all criteria

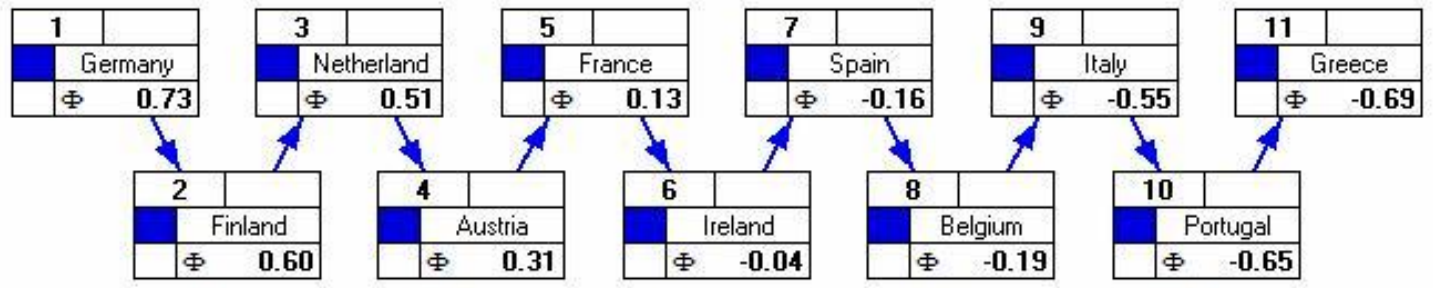

Source: Own elaboration based on Eurostat data 
Figure 3. Complete Ranking (PROMETHEE II) for 2007 with significant criteria according to panel data estimation

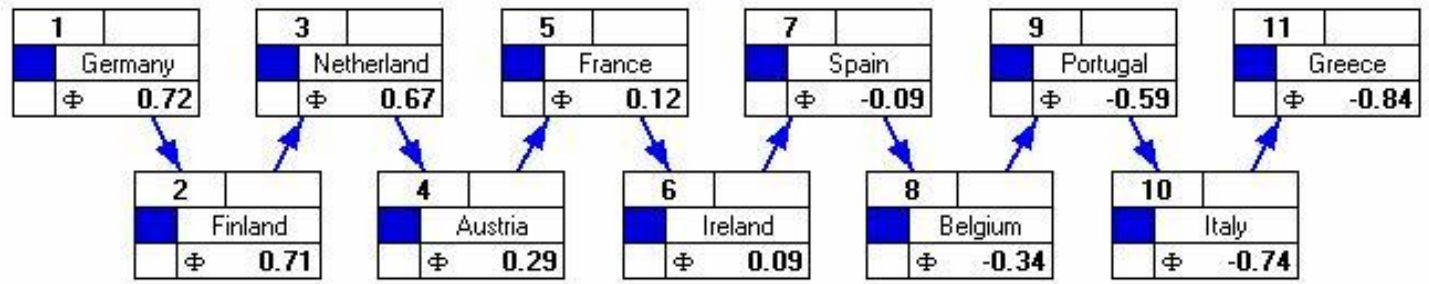

Source: Own elaboration based on Eurostat data

The results for 2007 show that there are not many changes when we use all criteria or when only use the significant criteria. On the other hand, we can appreciate a clear difference between central countries (Germany, Finland, Netherlands, Austria and France) and peripheral countries (among them, the best three are Ireland, Spain and Belgium, and the worst is Greece). Finally, if we compare these results with the position of these countries according to their risk premium we can affirm that the discrete multicrieteria methods adequately reproduce the ranking between countries on the basis of the used criteria (see Table 8).

According to the results of 2010 (Table 9 and Figures 4 and 5) can be seen again that the four countries better positioned are Finland, Germany, Netherland and Austria. When we use only the three significant variables (GDP growth, Public Debt and Current Account Balance) Belgium is in the same position than France while its position is slightly worse given the risk premium. On the other hand, the worst position is again for "peripheral" countries.

Table 9. Ranking for 2010 with all criteria

\begin{tabular}{|c|c|c|c|c|c|}
\hline 2010 & Phi Plus & Phi Minus & Phi Net & $\begin{array}{c}\text { Multicriteria } \\
\text { Ranking }\end{array}$ & $\begin{array}{c}\text { Risk Premium } \\
\text { Ranking }\end{array}$ \\
\hline Germany & 0.8571 & 0.1429 & 0.7143 & 1 & 1 \\
\hline Filand & 0.7857 & 0.2143 & 0.5714 & 2 & 3 \\
\hline Netherland & 0.6286 & 0.3571 & 0.2714 & 4 & 2 \\
\hline Austria & 0.7143 & 0.2714 & 0.4429 & 3 & 5 \\
\hline France & 0.5571 & 0.4429 & 0.1143 & 6 & 4 \\
\hline Ireland & 0.1286 & 0.874 & -0.7429 & 11 & 10 \\
\hline Belgium & 0.6286 & 0.3714 & 0.2571 & 5 & 6 \\
\hline Spain & 0.3000 & 0.7000 & -0.4000 & 8 & 8 \\
\hline Italy & 0.4286 & 0.5286 & -0.1000 & 7 & 7 \\
\hline Portugal & 0.2143 & 0.7714 & -0.5571 & 9 & 9 \\
\hline Greece & 0.2143 & 0.7857 & -0.5714 & 10 & 11 \\
\hline
\end{tabular}

A higher ranking value means a worse macroeconomic situation (multicriteria ranking) or higher risk premium (risk premium ranking).

Source: Own elaboration based on Eurostat data

Figure 4. Complete Ranking (PROMETHEE II) for 2010 year with all criteria

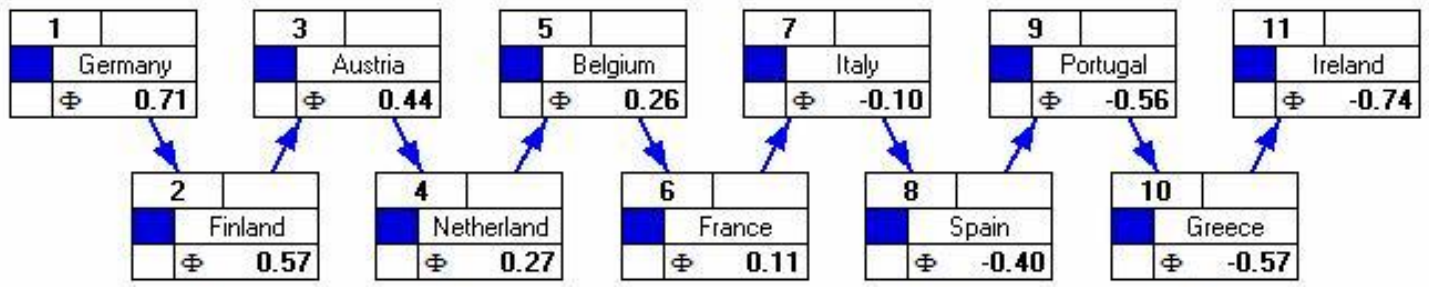

Source: Own elaboration based on Eurostat data 
Figure 5. Complete Ranking (PROMETHEE II) for 2010 year with significant criteria obtained in estimation of panel data model with fixed effect and quarterly data

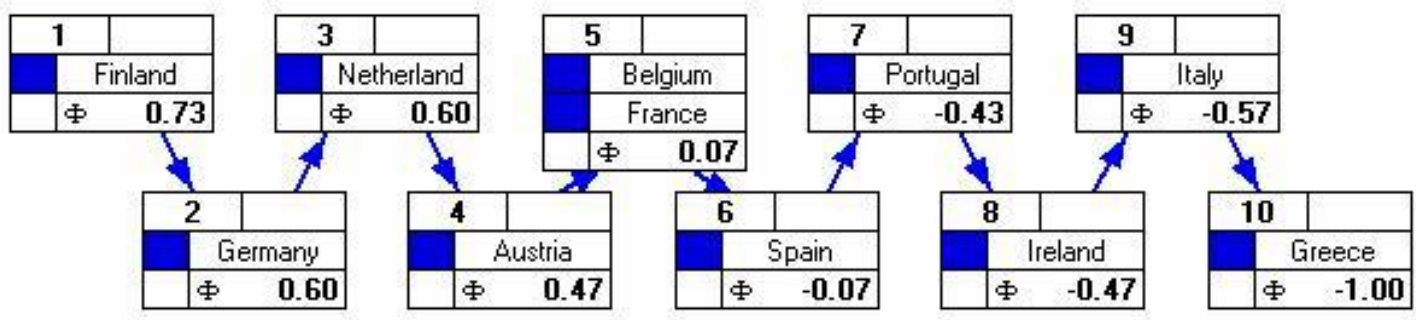

Source: Own elaboration based on Eurostat data

\section{CONCLUSIONS}

The analysis we have conducted shows that variations in the risk premium of individual EMU countries can be largely explained by changes in some macroeconomic variables. Specifically, during the current economic crisis (2007-2010) these variables are GDP growth, public debt and current account balance, although for a larger sample it would be GDP growth, private and public debt and public budget balance.

However, it should also be noted that Spain and Ireland have higher risk premiums than those that would result from their macroeconomic situation, while Italy and Belgium are in a relatively better position. This shows the need for further analysis of other factors, as speculation or "contagion" between groups of countries.

Regarding the analysis using discrete multicriteria decision aid methods, the results show its usefulness to build "rankings" of the countries of the monetary union. Specifically, we have ordered them according to their vulnerability to a debt crisis and higher risk premia, using for this purpose the information derived from the same macroeconomic variables.

\section{AUTHOR INFORMATION}

María del Carmen García-Centeno, PhD in Economics by CEU San Pablo University and Degree in Economics by University Complutense of Madrid. Lecturer in Statistics at Quantitative Methods Department. Faculty of Business and Economics. CEU San Pablo University. Madrid (Spain). E-mail: garcen@ceu.es.

Research Interest: Stochastic volatility, time series analysis, regional analysis.

Jorge Uxó-González, $\mathrm{PhD}$ in Economics and Degree in Economics by University Complutense of Madrid. Lecturer in Economic Theory at Economic Analysis and Finance Department. Faculty of Social Sciences of Cuenca. University of Castilla-La Mancha (Spain). E-mail: Jorge.Uxo@uclm.es.

Research Interest: Applied Macroeconomics, Monetary and Fiscal Policy, European Monetary Union.

Román Mínguez-Salido, $\mathrm{PhD}$ in Economics by CEU San Pablo University and Degree in Economics by University Complutense of Madrid. Msc in Mathematical Engineering by University Complutense of Madrid. Lecturer in Statistics at Statistics Department. Faculty of Social Sciences of Cuenca. University of Castilla-La Mancha (Spain). E-mail: Roman.Minguez@uclm.es.

Research Interest: Spatial econometrics, regional analysis, time series analysis. 


\section{REFERENCES}

1. Baltagi, B. H. (2005): Econometric Analysis of Panel Data. $3^{\text {rd }}$ Edition. Wiley. Chichester (UK).

2. Brans, J. P., Mareschal, B. and Vincke, P. H. (1984). "PROMETHEE: a new family of outranking methods in multicriteria analysis", in J. P Brans (ed.), Operational Research'84, North-Holland, pp. 477-490.

3. Brans, J. P. and Vincke, P. H. (1985). "A preference ranking organization method, the PROMETHEE method", Management Science, 31, pp. 647-656.

4. Deutsche Bank (2011). "Macroeconomic coordination. What can a scoreboard approach achieve?", Reports on European Integration, EU Monitor 78.

5. European Commission (2010). Economic governance package (2): Preventing and correcting macroeconomic imbalances, MEMO 10/454, 29th September.

6. Goumans, M. and Lygerou, V. (2000). "An extension of the PROMETHEE method for decision making in fuzzy environment: Ranking of alternative energy exploitation projects". European Journal of Operational Research, 123:3, 606-613.

7. $\quad$ Greene, W. H. (2008): Econometric Analysis. $7^{\text {th }}$ Edition. Prentice-Hall. New Jersey (USA).

8. Gros, D. and T. Mayer (2010). "How to deal with sovereign default in Europe: Create the European Monetary Fund now!”, CEPS Policy Brief, n 202. 


\section{NOTES}

